\title{
FAKTOR YANG MEMPENGARUHI KEPUASAN WISATAWAN BERKUNJUNG DI SERANGAN DENPASAR BALI
}

\author{
I Made Weda Satia Negara \\ Universitas Udayana \\ Email: wedasatia.made@gmail.com \\ I Nyoman Sudiarta \\ Universitas Udayana \\ Email: sudiarta.nyoman@yahoo.co.id \\ I Wayan Suardana \\ Universitas Udayana \\ Email: suar.dana@gmail.com
}

\begin{abstract}
Serangan located in South Denpasar is a tourist destination, visited by many foreign and domestic tourists. The purpose of this study is to determine the characteristics of tourists and seeking the dominant factors affecting the satisfaction of tourists visiting tourist attractions in Serangan. This study uses a survey research design with a sample of 180 respondents. By using a factor analysis technique and processed using the IBM SPSS version 23. The results of the factor analysis have been identified that there are six factors form the satisfaction of tourists visiting tourist attractions in Serangan. First Factors include the beach, the attractive scenery, the peace and quiet and the tourist attraction factor. Factors 2 namely, hygiene, cultural activity, sports activity and information factors. Factors 3 namely, weather, food and cost factor. Factors 4 encompass lodging, historical place, attractive village and access factor. Factors 5 are the boat service and the local community life factor. Factor 6 is safety. From these 6 groups of factors found that the most dominant is beach factor which has influenced the satisfaction of tourists visiting tourist attractions in Serangan. Based on the findings of this study, it is hope that the government preserves the main factors forming the satisfaction of tourists who visit the tourist attraction in Serangan island.
\end{abstract}

Keywords: Satisfaction, Attraction, Tourists, Serangan. 


\section{Pendahuluan}

Pariwisata adalah salah satu industri yang mampu menghasilkan devisa negara dengan mendatangkan wisatawan baik wisatawan mancanegara dan nusantara. Menurut Gunn (dalam Yoeti 2005:52) untuk menetapkan sasaran pariwisata pada suatu daya tarik wisata perlu mempersiapkan asesibilitas fasilitas dan daya tarik pariwisata sedemikian rupa sehingga bila wisatawan berkunjung ke daya tarik wisata tersebut merasa puas, senang dan sesuai dengan harapannya Kurangnya infrastruktur atau aksesibilitas pada suatu destinasi pariwisata menjadi kendala dan citra yang kurang baik terhadap suatu daya tarik wisata. Terbatasanya transportasi juga menjadi kendala bagi wisatawan dan informasi yang negatif bagi calon wisatawan terhadap suatu destinasi pariwisata. Menurut Gaspersz (2005:35), faktor-faktor yang mempengaruhi kepuasan dan ekspektasi pelanggan terdiri dari: "kebutuhan dan keinginan" yang berkaitan dengan hal-hal yang dirasakan pelanggan ketika ia sedang mencoba melakukan transaksi dengan produsen jasa.

Kepuasan (satisfaction) menurut Kotler (2005:70) yaitu perasaan kecewa ataupun senang yang dirasakan oleh seseorang yang timbul setelah membandingkan antara kinerja produk yang dipikirkan terhadap kinerja (atau hasil) yang diharapkan. Kepuasan wisatawan merupakan ukuran keseluruhan dari pendapat wisatawan pada setiap kualitas destinasi Prayag, 2008 (dalam Coban, 2012). Ukuran tersebut dapat dipertimbangkan sebagai nilai mengenai kualitas hasil dari destinasi pariwisata, misalnya perlakuan dan pelayanan yang dirasakan wisatawan terhadap destinasi pariwisata, tetapi tidak hanya hasil pada akhir pengalamannya Coban (2012).

Sudiarta dan Suardana (2014) menyatakan bahwa perilaku konsumen adalah entitas penting dalam strategi pemasaran, khususnya strategi pemasaran tujuan wisata. Bertujuan untuk mempelajari perilaku wisatawan setelah mengunjungi obyek wisata di Bali. Penelitian ini menggunakan dua pendekatan atau kombinasi 
metode kualitatif (eksplorasi) dan kuantitatif (konfirmasi) dan dengan kegiatan focus group discussion (FGD), dengan stakeholder pariwisata khususnya. Populasi dalam penelitian ini adalah wisatawan mancanegara yang mengunjungi ketiga Objek wisata utama. Pengumpulan data dilakukan studi konfirmatori dengan menggunakan kuesioner diberikan kepada wisatawan yang telah berada di tiga objek wisata utama tersebut. Hasil dari penelitian ini menunjukkan bahwa penyebab dari kepuasan wisatawan yang paling tinggi adalah akomodasi $12 \%$, iklim $10 \%$ dan daya tarik wisata $7 \%$.

Menurut Tjiptono (2002:146) konsep kepuasan pelanggan masih bersifat abstrak karena pencapaian kepuasan dapat merupakan proses yang sederhana maupun komplek atau rumit. Pelayanan adalah aktifitas tidak kasat mata atau bersifat intangible. Pelayanan disediakan oleh semua sektor seperti ekonom, retail, pedagang besar,transportasi, telekomunikasi, keuangan, kesehatan, pendidikan, dan banyak sektor lainnya, termasuk pariwisata, hospitality dan leisure Reseinger dan Turner (2003: 134).

Salah satu daerah tujuan pariwisata yang sudah diakui keberadaannya oleh dunia internasional adalah Bali. Bali banyak sekali memiliki daerah tujuan pariwisata yang memiliki keindahan alam yang khas serta masyarakat yang masih menunjang tinggi adat istiadat dan kebudayaannya. Kepariwisataan merupakan suatu industri yang berkembang pesat di seluruh dunia saat ini, seluruh negara berlomba-lomba mengembangkan kepariwisataan dan berusaha menarik minat wisatawan untuk datang berkunjung ke daerah tujuan wisata.

Kota Denpasar yang dimiliki Bali salah satu destinasi wisata yang diminati oleh wisatawan. Kota Denpasar yang memiliki lokasi yang sangat strategis, sarana dan prasarana wisata sebagai salah satu keunggulan. Kota Denpasar mampu menjadi salah satu destinasi wisata yang patut di perhitungkan di Bali. Dari Dinas Pariwisata Propensi Bali, dapat dilihat kunjungan dan pertumbuhan wisatawan 
pada objek dan daya tarik wisata di Kota Denpasar, pada tahun 2011 berjumlah 398.025, tahun 2012 berjumlah 395.558 atau $0.61 \%$ tahun 2013 berjumlah 443.775 atau $12.18 \%$, tahun 2014 berjumlah 542.813 atau $22.31 \%$ dan tahun 2015 berjumlah 445.961 atau $-16 \%$. Dilihat dari perkembangan jumlah kunjungan dan pertumbuhan wisatawan pada objek dan daya tarik wisata di Kota Denpasar jumlah kunjungan dan pertumbuhan wisatawan dari tahun ketahun berikutnya terus mengalami peningkatan.

Salah satu tempat tujuan wisata yang ada di Denpasar selatan adalah Serangan Denpasar yang memiliki potensi pariwisata bahari seperti surfing (selancar), fishing (memancing), diving (menyelam) dan kegiatan aktifitas wisata bahari lainnya. Serangan memeliki potensi aktifitas kepariwisataan yang sangat diminati dan di kenal wisatawan sebagai kegiatan aktifitas pariwisata bahari, pantai yang indah bagus untuk berselancar, snorkeling, memancing dan sudah menyediakan sarana watesport sebagai penunjang sarana aktifitas wisata bahari. Kelurahan serangan banyak di kunjungi wisatawan mancanegara dan nusantara karena memeliki potensi wisata, terumbu karang, mangrove, rumput laut, padang lamun, keanekaragaman biota laut, sungai buatan atau yang di sebut kanal, berkuda di pantai, makanan khas ikan bakar Serangan, kegiatan ritual keagamaan, kesenian masyarakat yang sebagai penunjang kegiatan pariwisata. Perasaan senang atau kecewa seseorang yang muncul setelah membandingkan antara kinerja (hasil) produk yang dipikirkan terhadap kinerja (hasil) yang diharapkan. Jika kinerja berada dibawah harapan, pelanggan tidak puas. Jika kinerja memenuhi harapan, pelanggan puas. Jika kinerja melebihi harapan, pelanggan amat puas atau senang Kotler (2003:70). Dalam dunia hospitaliti, khususnya di bidang pariwisata, sangatlah penting bagi perusahaan untuk dapat mencapai kepuasan wisatawan secara maksimal karena dengan kepuasan wisatawan yang sangat maksimal, akan dapat menciptakan kunjungan kembali wisatawan (repeated guest). Salah satu yang dapat dilakukan adalah dengan menyediakan produk pariwisata yang sesuai dengan 
keinginan dan kebutuhan wisatawan. Menurut Schiffman dan Kanuk (2007:9) kepuasan pelanggan merupakan persepsi individu dari kinerja produk atau pelayanan dalam hubungannya dengan harapan (ekspektasi) pelanggan itu sendiri. Masing- masing individu akan memiliki ekspektasi yang berbeda - beda.

Dalam usaha mencapai suatu keunggulan dalam industri pariwisata adalah dengan memperoleh banyak pengunjung dan bisa mengungguli pesaing. Untuk itulah setiap orang yang terkait di dalamnya dituntut agar dapat melakukan pekerjaan dengan lebih baik, yang memenuhi dan memuaskan kebutuhan wisatawan secara maksimal. Menurut Wyckof, (dalam Tjiptono 2014:268), kualitas pelayanan adalah tingkat keunggulan yang diharapkan dan pengendalian atas tingkat keunggulan tersebut untuk memenuhi keinginan pelanggan. Dengan adanya kualitas yang baik di dalam suatu usaha pariwisata, akan menciptakan kepuasan bagi wisatawannya. Wisatawan yang merasa benar-benar puas akan kembali bahkan memberikan rekomendasi kepada orang lain untuk berkunjung. Namun apabila wisatawan tidak merasa puas dari objek wisata tersebut, maka mereka akan meninggalkannya dengan membawa kesan yang kurang baik. Dalam jangka panjang hal tersebut akan menyebabkan penurunan jumlah kunjungan yang dapat merugikan objek wisata itu sendiri. Oleh karena itu diperlukan upaya mempertahankan dan meningkatkan kualitas objek wisata tersebut agar wisatawan bisa memperoleh apa yang diharapkan bahkan lebih.

Serangan Denpasar banyak dikunjungi wisatawan mancanegara dan nusantara selain tempat daya tarik wisata yang ada di Bali pada khususnya di Denpasar. Dengan banyaknya kunjungan wisatawan mancanegara dan nusantara di Serangan, ada bererapa wisatawan yang memberikan keluhan tentang kepuasannya selama berkunjung ke Serangan dan wisatawan memberikan berbagai komentar mulai dari komentar positif sampai komentar negatif, penelitian tentang faktor yang mempengaruhi kepuasan wisatawan berkunjung ke Serangan perlu dilakukan 
untuk dapat mengetahui faktor yang mempengaruhi kepuasan wisatawan berkunjung ke daya tarik wisata di Serangan. Dengan mengetahui faktor yang mempengaruhi kepuasan wisatawan berkunjung di Serangan, maka manfaat sebaliknya pihak dari Kelurahan Serangan akan dapat menilai yang dapat memenuhi dan memuaskan wisatawan berkunjung di Serangn. Sehubungan dengan latar belakang masalah diatas, rumusan masalah dalam penelitian ini adalah 1) Bagaimana karakteristik wisatawan yang berkunjung di daya tarik wisata di Serangan? 2) Apa saja faktor-faktor yang dominan mempengaruhi kepuasan wisatawan ketika berkunjung di daya tarik wisata di Serangan?.

\section{Teori dan Metode Penelitian}

Penelitian ini menggunakan teori kepuasan. Kepuasan adalah tingkat perasaan seseorang setelah membandingkan kinerja/hasil yang dirasakan dengan harapan Oliver (dalam Supranto 2006:233). Kepuasan pelanggan merupakan suatu hal yang menjadi harapan perusahaan khususnya dibidang hospitality. Kepuasan diperoleh apabila kebutuhan dan keinginan pelanggan terpenuhi, sedangkan keinginan dan kebutuhan manusia selalu berubah dan tidak ada batasnya. Menurut Mill and Morrison (2009:17) destinasi pariwisata digambarkan sebagai bauran antara berbagai item, yang disingkat dengan AFITH. Elemen tersebut adalah: 1) attraction, 2) facilities, 3) infrastructure, 4) transportation dan 5) hospitality. Penelitian ini menggunakan metode kuantitatif yang di dukung oleh data-data kualitatif dan didesain dengan rancangan penelitian survai yang melibatkan wisatawan mancanegara dan nusantara yang berkunjung di daya tarik wisata di Serangan. Penelitian ini akan mengaevalusi kepuasan wisatawan pasca melakukan perjalanan wisata dengan cara mengukur kepuasan mereka. Sehingga kuesioner yang diberikan kepada wisatawan setelah mereka menikmati daya tarik wisata pada saat berkunjung dan atau setelah berkunjung namun masih berada di Serangan. 
Penelitian ini menggunakan metode kuantitatif yang di dukung oleh datadata kualitatif dan didesain dengan rancangan penelitian survai yang sebagai responden wisatawan mancanegara dan nusantara yang berkunjung didaya tarik wisata di Serangan Denpasar. Lokasi penelitian yang berada di Kelurahan Serangan Denpasar Bali.Penelitian ini adalah penelitian ekplanatori, menurut Sugiyono (2012:21) penelitian eksplanatori merupakan penelitian yang bermaksud menjelaskan kedudukan variabel - variable yang di teliti serta hubungan antara satu variabel dengan yang lain. Jenis data yang di gunakan dalam penelitian ini adalah data kuantitatif dan data kualitatif. Berdasarkan sumbernya. Penelitian ini di menggunakan data primer dan sekunder.

Metode pengambilan sampel dalam penelitian ini adalah dengan meggunakan teknik Porposive sampling. Jumlah sampel akan ditentukan berdasarkan hasil perhitungan sampel minimumadapun rumus penentuan sampel jumlah indikator variabel observasi dikalikan 5(lima), 10 sepuluh 15 (lima belas) atau 20 (dua puluh) Hair, et al(2006:98-99). Hal ini dimaksud adalah jika item kuesioner dirancang sebanyak 20 item, maka ukuran sampel minimal adalah $20 \times 10=200$. Dalam penelitian ini mempunyan jumlah total variable/indikator 18.Untuk menghitung jumlah responden, maka jumlah total indikator pertanyaan dikalikan 5 atau 10 dengan hasil perhitungan sebagai berikut : 18 × $10=180$ responden. 


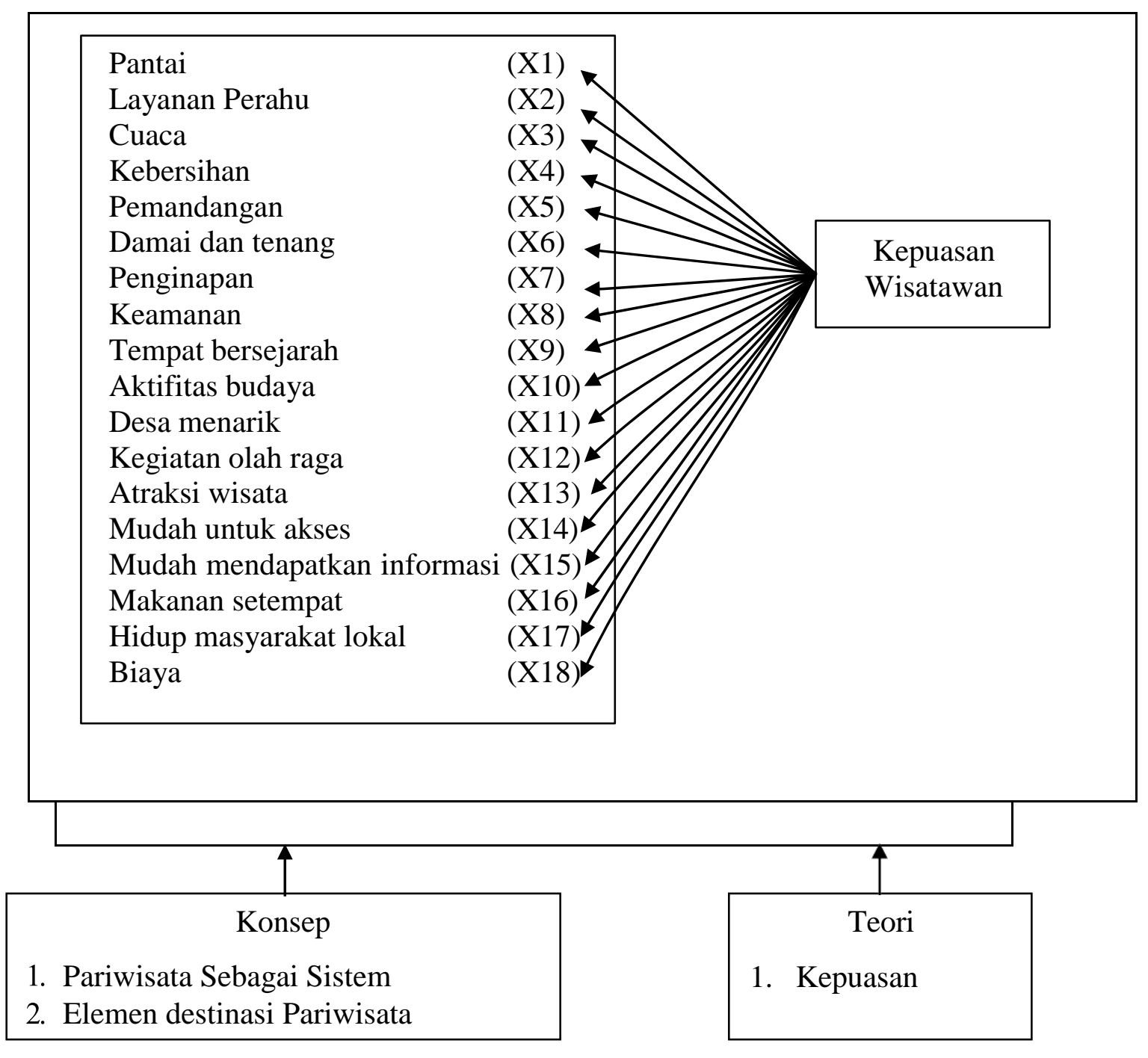

Gambar 1. Kerangka Berpikir dan Konsep Penelitian

Sekala likert digunakan untuk mengukur sikap, pendapat dan persepsi seseorang atau sekelompok orang tentang fenomena sosial. Dengan skala likert, maka variabel yang di ukur dijabarkan menjadi indikator variabel. Kemudian indikator tersebut dijadikan sebagai titik tolak untuk menyusun item-item instrumen yang dapat berupa pertanyaan atau pernyataan Sugiyono (2015:132). Hasil penelitian ini dianalisis menggunakan metode analisis deskriptif kuantitatif dengan bantuan statistik SPSS 23. Analisis faktor adalah salah satu teknik analisis multivariate, yang merupakan bagian dari model hubungan variabel yang bersifat interdependensi. Metode multivariate sesungguhnya terdiri dari model hubungan model independen dan model hubungan interdependensi Hair et al (dalam 
Widarjono 2010: 240). Analisi korelasi matrik antar indikator dalam hal ini digunakan untuk mengetahui apakah indikator - indikator kepuasan wisatawan layak dianalisis menggunkan analsis faktor. Syarat kecukupan pertama adalah dari KMO MSA (Kaiser Meyer Olkin Measure of sampling adequacy dan Barlett's test). Jika KMO MSA lebih besar dari 0,5 maka dianggap memenuhi syarat kecukupan untuk analisis faktor. Langkah kedua dalam analisis faktor adalah ekstraksi faktor dengan Principal Components Analysis (PCA). Melakukan rotasi faktor untuk menghasilkan komponen utama yang jelas.

\section{Analisis Statistik Karakteristik Wisatawan}

Sebelum sampai kepada fokus penelitian ini yakni faktor yang mempengaruhi kepuasan wisatawan berkunjung di Serangan, akan di ungkapkan terlebih dahulu karakteristik wisatawan. Di lihat dari kebangsaan wisatawan bahwa wisatawan yang menjadi responden meliputi 118 orang atau 65.6\% dari dalam negeri dan 62 orang atau 34.4\% wisatwan dari luar negeri. Berdasarkan data di atas, dapat di simpulkan bahwa mayoritas responden dalam penelitian ini merupakan wisatawan yang berasal dari dalam negeri. Berdasarkan status pernikahan bahwa lebih banyak responden yang berkunjung di Serangan dengan status belum menikah yaitu sebabyak 148 oranga atau $82.2 \%$, sisanya berstatus sudah menikah sebanyak 32 orang atau $17.8 \%$. Di lihat dari karakteristik wisatawan berdasarkan jenis kelamin wisatawan bahwa responden dengan jenis kelamin laki-laki berjumlah sebanyak 76 atau $42.2 \%$, sedangkan responden dengan jenis kelamin perempuan berjumlah sebanyak 104 atau 57.8\%. di lihat dari jenis kelamin, ada kecendrungan bahwa wisatawan perempuan lebih banyak dari pada wisatawan laki-laki yang berkunjung di Serangan walaupun dengan perbedaan tidak terlalu mencolok. Karteristik wisatawan berdasarkan usia responden dengan usia 17-23 tahun sebanyak 108 orang atau $60.0 \%$, 24-30 tahun sebanyak 39 orang atau 21.7\%, 31-37 tahun sebanyak 19 orang atau $10.6 \%, 38-44$ sebanyak 5 orang atau 2,8\%, 45-51 tahun sebanyak 3 orang 
atau $1.7 \%$ dan dengan usia 51 keatas sebanyak 5 orang atau 3.3\%. Hal ini menunjukkan bahwa mayoritas usia responden dalam penelitian ini adalah 17-23 tahun yaitu $60.0 \%$, yang di ikuti dengan usia 24-30 tahun atau 21.7\%. yang berarti sebagian besar wisatawan dengan usia 17-23 tahun dengan jumlah $60.0 \%$ yang berkunjung di Serangan. Di lihat dari karakteristik wisatawan berdasarkan latar belakang pendidikan terakhir mulai dari tingkat sekolah menengah atas sampai tingkat Doktor. Komposisi data responden menurut hasil penelitian membuktikan bahwa hanya $1.1 \%$ responden dengan latar belakang pendidikan doktor, kemudian pasca $8.3 \%$, diploma $12.8 \%$ dan dengan latar belakang pendidikan sarjana $14.4 \%$ ,sedangkan latar belakang pendidikan SMA 63.3\% yang mendominasi karena di pengaruhi oleh faktor ekonomi, minat akan pengalaman bertualang dan waktu luang yang tersedia wisatawan untuk melakukan kunjungan. Di lihat dari karakteristik wisatawan berdasarkan pekerjaan adalah pelajar/mahasiswa dan pegawai swasta dengan komposisi : pelajar/mahasiswa sebanyak 51.7\% dan pegawai sebanyak $26.7 \%$ sedangkan yang lainnya berkisar $17.2 \%$ hingga $4.4 \%$. Karakteristik responden menurut pekerjaan atau kegiatan utama di dominasi oleh pelajar atau mahasiswa. Hal ini di pengaruhi oleh adanya ketersedian waktu luang, stamina secara fisik masih prima dan rasa ingin tahu yang masih tinggi yang di miliki oleh wisatawan tersebut. Sedangkan responden yang berlatar belakang pegawai di pengaruhi oleh keinginan untuk mengisi waktu luang, rekreasi diri dan melepaskan diri sejenak dari kejenuhan rutinitas pekerjaan setiap hari kerja. Di lihat dari karakteristik wisatawan berdasarkan tujuan berkunjung adalah seluruh wisatawan yang menjadi responden dalam penelitian ini tujuan utamanya datang di Serangan sebagai Wisatawan ( Berlibur ) terbanyakyaitu dengan jumlah 139 orang atau sebesar 77.2 \% bukan dalam urusan pekerjaan atau kegiatan yang mendatangkan penghasilan di lihat dari karaktersik wisatawan berdasarkan sumber informasi yang di peroleh adalah sebagian besar wisatawan mendapatkan informasi yang bersumber dari temannya, yaitu sebanyak 100 orang atau 55.6\%. sumber informasi 
selanjutnya adalah di dapat dari media oleh wisatawan sebanyak 57 orang atau $31.7 \%$, dari sumber brosur adalah sebanyak 13 orang atau $7.2 \%$ dan sisanya sebanyak 10 orang wisatawan atau 5.6\% memperoleh informasi dari sumber lainnya. Dilihat dari karakteristik wisatawan berdasarkan frekuensi kunjungan terlihat bahwa umumnya bagi yang berkunjungan berulang terkonsentrasi pada frekuensi kunjungan sebanyak lebih dari empat kali atau 18.34\% kemudian di susul dengan frekuensi kunjungan sebanyak 3 kali 18.9\%, 2 kali 19.4\%, dan 1 kali atau 43.3\%.

\section{Analisis Statistik Kuantitatif Faktor Dominan Kepuasan Wisatawan}

Langkah-langkah yang dilakukan terlebih dahulu sebelum melakukan analisis faktor yaitu, melakukan uji validitas dan reliabilitas intrumen. Tujuan melakukan uji validitas dan reliabilitas untuk mengetahui sejauh mana ketepatan dan konsitensi suatu intrumen pengukuran dalam melakukan fungsi ukurnya. Suatu intrumen atau suatu item pertanyaan di nyatakan valid jika $r$ hitung $>\mathrm{r}$ tabel. Hasil $r$ tabel akan mengikuti nilai dari $n=180$, dengan tingkat signifikan $5 \%(0,5)$ dan di temukan bahwa r tabel adalah 0.195 ( Arikunto,2002).

Pengecekan Anti image matrices untuk mengetahui apakah indikator-indikator secara parsial layak untuk di analisis dan di keluarkan dalam pengujian. Berdasarkan tabel di atas, terlihat bahwa dari 18 indikator yang akan di analisis semuanya memiliki nilai MSA > 0.5, yang artinya layak untuk di lakukan anlisis faktor.

Langkah selanjutnya melakukan ekstraksi faktor. Analisis ini menghasilkan nilai communalities dan total variance explained. Pada total variance dapat di ketahui initial eigenvalues> 1 menunjukkan bahwa faktor tersebut dapat menjelaskan indikator dengan baik dan perlu di sertakan dalam pembentukan variabel Widarjono (2010:250). Ada pun hasil total variance, yaitu analisis ini menghasilkan 6 komponen dari 18 indikator pembentuk faktor yang mempengaruhi kepuasan 
wisatawan berkunjung di Serangan. Adapun hasil total variance seperti di sajikan pada Tabel 1.

Tabel 1. Total Variance Explained

\begin{tabular}{|c|c|c|c|c|c|c|c|c|c|}
\hline \multirow{2}{*}{ Component } & \multicolumn{3}{|c|}{ Initial Eigenvalues } & \multicolumn{3}{|c|}{$\begin{array}{c}\text { Extraction Sums of Squared } \\
\text { Loadings }\end{array}$} & \multicolumn{3}{|c|}{$\begin{array}{c}\text { Rotation Sums of Squared } \\
\text { Loadings }\end{array}$} \\
\hline & Total & $\begin{array}{c}\% \text { of } \\
\text { Variance }\end{array}$ & $\begin{array}{c}\text { Cumulative } \\
\%\end{array}$ & Total & $\begin{array}{c}\% \text { of } \\
\text { Variance }\end{array}$ & Cumulative\% & Total & $\begin{array}{c}\% \text { of } \\
\text { Variance }\end{array}$ & $\begin{array}{c}\text { Cumulative } \\
\%\end{array}$ \\
\hline 1 & 4.797 & 26.651 & 26.651 & 4.797 & 26.651 & 26.651 & 2.945 & 16.362 & 16.362 \\
\hline 2 & 1.927 & 10.705 & 37.356 & 1.927 & 10.705 & 37.356 & 2.263 & 12.572 & 28.933 \\
\hline 3 & 1.528 & 8.489 & 45.845 & 1.528 & 8.489 & 45.845 & 2.124 & 11.799 & 40.733 \\
\hline 4 & 1.467 & 8.153 & 53.998 & 1.467 & 8.153 & 53.998 & 1.814 & 10.079 & 50.812 \\
\hline 5 & 1.296 & 7.203 & 61.200 & 1.296 & 7.203 & 61.200 & 1.571 & 8.726 & 59.538 \\
\hline 6 & 1.008 & 5.599 & 66.800 & 1.008 & 5.599 & 66.800 & 1.307 & 7.262 & 66.800 \\
\hline 7 & .890 & 4.943 & 71.743 & & & & & & \\
\hline 8 & .775 & 4.305 & 76.048 & & & & & & \\
\hline 9 & .762 & 4.231 & 80.279 & & & & & & \\
\hline 10 & .576 & 3.199 & 83.478 & & & & & & \\
\hline 11 & .531 & 2.949 & 86.427 & & & & & & \\
\hline 12 & .491 & 2.727 & 89.154 & & & & & & \\
\hline 13 & .448 & 2.491 & 91.645 & & & & & & \\
\hline 14 & .393 & 2.185 & 93.829 & & & & & & \\
\hline 15 & .336 & 1.866 & 95.695 & & & & & & \\
\hline 16 & .299 & 1.663 & 97.358 & & & & & & \\
\hline 17 & .256 & 1.423 & 98.781 & & & & & & \\
\hline 18 & .219 & 1.219 & 100.000 & & & & & & \\
\hline
\end{tabular}

Sumber : Hasil Penelitian 2017

Pada Tabel 1 dapat di baca bahwa niali egenvalue lebih dari satu atau sama dengan 1, maka dapat di ketahui bahwa 6 faktor yang terbentuk dari 18 indikator yang membentuk faktor yang mempengaruhi wisatawan berkunjung ke daya tarik wisata di Serangan. Dalam analisis faktor prosedur yang dilakukan selanjutnya adalah melakukan rotasi faktok untuk menghasilkan komponen utama yang jelas. Tujuan dari rotasi ini adalah untuk dapat memperoleh struktur faktor yang lebih sederhana agar mudah untuk di interpretasikan. Metode yang umumnya di gunakan adalah Varimax Method suatu rotasi Orthogonal untuk meminimalis jumlah indikator yang mempunyai faktor loading yang tinggi pada tiap faktor Widiarjono (2010 : 244). Hasil total varian dapat di baca seperti Tabel 2. 
Tabel 2. Rotated Component Matrix

\begin{tabular}{|c|l|c|c|c|c|c|c|}
\hline \multicolumn{2}{|c|}{} & \multicolumn{7}{|c|}{ Component } \\
\cline { 2 - 8 } \multicolumn{2}{|c|}{} & 1 & 2 & 3 & 4 & 5 & 6 \\
\hline X1 & Pantai & .848 & .081 & .056 & .167 & .066 & .084 \\
\hline X2 & Layanan Perahu & .101 & .078 & -.082 & -.001 & .655 & .554 \\
\hline X3 & Iklim & -.044 & .112 & .833 & .152 & .090 & .127 \\
\hline X4 & Kebersihan & .392 & .603 & -.007 & .156 & -.153 & .288 \\
\hline X5 & Pemandangan & .801 & .221 & .063 & .130 & -.106 & .077 \\
\hline X6 & Damai dan tenang & .684 & .120 & .109 & .020 & .249 & .038 \\
\hline X7 & Penginapan & .260 & .064 & .011 & .632 & .290 & -.407 \\
\hline X8 & Keamanan & .180 & .112 & .152 & .143 & .197 & .792 \\
\hline X9 & Tempat bersejarah & .110 & .227 & .140 & .633 & .125 & -.018 \\
\hline X10 & Aktifitas budaya & .119 & .655 & .231 & -.013 & .431 & -.123 \\
\hline X11 & Desa menarik & .101 & .272 & .029 & .645 & -.033 & .133 \\
\hline X12 & Kegiatan olahraga & .170 & .740 & .024 & .250 & -.001 & .135 \\
\hline X13 & Atraksi wisata & .832 & .229 & .069 & -.049 & .140 & .012 \\
\hline X14 & Mudah untuk akses & -.059 & -.119 & .090 &. $\mathbf{6 2 5}$ & -.028 & .126 \\
\hline X15 & Mudah mendapatkan & .177 & .787 & .093 & .030 & .005 & -.019 \\
& informasi & & & & & & \\
\hline X16 & Makanan setempat & .177 & .053 & .779 & .010 & .068 & -.096 \\
\hline X17 & Hidup masyarakat lokal & .139 & -.009 & .082 & .132 & .824 & .083 \\
\hline X18 & Biaya & .095 & .054 & .820 & .104 & -.062 & .093 \\
\hline
\end{tabular}

Sumber : Hasil Penelitian 2017

Dari hasil rotasi yang ditunjukkan pada Tabel 2 dapat di lihat bahwa ada enam komponen yang terbentuk. Komponen 1 yang terdiri dari :1) faktor kepuasan kondisi alam berupa pantai, 2) faktor kepuasan melihat pemandangan yang menarik,3) damai dan tenang dan 4) atraksi wisata. Komponen 2 yang terdiri dari : 1) faktor kebersihan,2) faktor aktifitas budaya,3) faktor kegiatan olah raga dan 4) faktor informasi. Komponen 3 yang terdiri dari faktor : 1) faktor cuaca, 2) faktor makanan, dan 3) biaya. Komponen 4 terdiri dari : 1) faktor penginapan, 2) tempat bersejarah dan 3) faktor desa menarik dan 4) faktor mudah untuk akses. Komponen 5 terdiri dari : 1) layanan Perahu dan 2) faktor Hidup masyarakat lokal. Komponen 6 terdiri dari : 1) faktor keamanan. Dengan demikian hasil dari analisis faktor yang disajikan pada tabel di atas menjawab rumusan masalah dari penelitian ini, yaitu yang mempengaruhi kepuasan wisatawan yang berkunjung ke daya tarik wisata di Serangan adalah faktor 1 (satu) berdasarkan hasil penelitian yang mempengaruhi 
kepuasan wisatawan yang berkunjung di daya tarik wisata di Serangan yang terbentuk pada faktor 1 yang terdiri dari faktor kondisi alam berupa pantai (X1), melihat pemandangan yang menarik (X5), damai dan tenang (X6) dan atraksi wisata (X13). Berdasarkan hasil penelitian Pada tabel 5.18 yang membentuk faktor 1 yang mempengaruhi kepuasan wisatawan berkunjung di daya tarik wisata di Serangan, faktor kondisi alam berupa pantai berada pada katagori paling tinggi, hal ini berarti bahwa indikator pantai yang ada di Serangan memberikan kepuasan yang baik dan diberikan skor yang paling tinggi oleh mayoritas responden.

\section{Simpulan dan Saran}

Berdasarkan hasil dan pembahasan yang telah diuraikan, dapat di simpulkan bahwa pembentuk kepuasan wisatawan berkunjung di daya tarik wisata di Serangan terdapat 6 faktor yang terbentuk dari 18 indikator yang di gunakan untuk menganalisis kepuasan wisatawan yang berkunjung. Terbentuk 6 (enam) faktor yaitu, faktor 1 (satu) yang terdiri dari:1)faktor kepuasan kondisi alam berupa pantai, 2) faktor kepuasan melihat pemandangan yang menarik,3) damai dan tenang dan 4) atraksi wisata. Faktor 2 (dua) yang terdiri dari : 1) faktor kebersihan, 2) faktor aktifitas budaya, 3) faktor kegiatan olah raga dan 4) faktor informasi. Faktor 3 (tiga) yang terdiri dari faktor : 1) faktor cuaca, 2) faktor makanan, dan 3) biaya. Faktor 4 (empat) terdiri dari : 1) faktor penginapan, 2) tempat bersejarah dan 3) faktor desa menarik dan 4) faktor mudah untuk akses. Faktor 5 (lima) terdiri dari : 1) layanan Perahu dan 2) faktor Hidup masyarakat lokal dan faktor 6 (enam) terdiri dari : 1) faktor keamanan. Dari ke 6 (enam) komponen yang membentuk faktor kepuasan wisatawan berkunjung di daya tarik wisata di Serangan yang memiliki pengaruh yang paling besar adalah : faktor kepuasan kondisi alam berupa pantai, faktor kepuasan melihat pemandangan yang menarik dan faktor atraksi wisata. Dari ke delapan belas indikator yang di gunakan untuk mengetahui faktor- faktor yang mempengaruhi kunjungan wisatawan daya tarik wisata di Serangan yang paling 
dominan yaitu di temukan pada indikator kepuasan kondisi alam berupa pantai 0,848, indikator atraksi wisata 0,832 dan indikator kepuasan melihat pemandangan yang menarik 0,832. Sedangkan indikator yang terendah adalah indikator kebersihan 0,603. Adapun saran yang dapat disampaikan adalah, agar pemerintah mempertahankan tiga utama pembentuk kepuasan wisatawan yang berkunjung dan perbaikan perlu dilakukan dalam hal kepuasan kebersihan, penelitian dimasa mendatang perlu melakukan penelitian ulang untuk mendapatkan hasil yang konsisten dan menambahkan variabel dan indikator yang lebih banyak sebagai bentuk kepuasan.

\section{Daftar Pustaka}

Alegre, Joaquin dan Garau, Jaume. 2010. Tourist Satisfacion and Dissatisfaction and Behavioral Intention, Annal of Tourism Research, Vol.27, No. 3, pp. 57-73.

Coban, S. 2012. The Effects of The Image Destination on Tourist Satisfaction and Loyalty : The Case of Cappadocia European Journal of Social Sciences, 29 (2) : 222-232.

Dinas Pariwisata Propensi Bali. 2016. Bali Tourism Statistic. Denpasar : Dinas Pariwisata Provensi Bali.

Gasperz, V. 2005. Lean Sigma Approach. Jakarta: Penerbit Erlangga.

Hair, J.F., W.C. Black, B.J. Babin, R.E. anderson, R.L.Tatham.2006. Multivariate Data Analysis, 6 Ed., New Jersey : Prentice Hall.

Kotler, Philip. 2003. Manajemen Pemasaran. Edisi Kesebelas, Jakarta: Indeks kelompok Gramedia.

Kotler, Philip. 2005. Manajemen Pemasaran. Jilid Satu, Jakarta: Indeks kelompok Gramedia. Mill and Morrison, Alastair. 2009. The Tourism System, Sixth Edition, USA: Kendall Hunt. Reisinger, Yvette and Turner, Lindsay. 2003. Cross-Cultural Behaviour in Tourism :

Concept and analysis. Oxford Butterworth-Heinemann.

Schiffman, Leon G and Leslie Lazar Kanuk. 2007. Consumer Behaviour. Ninth Edition.

New Jersey: Pearson Education, Inc.

Sudiarta, I. N. dan Suardana,I. W. 2014. "Model Konseptual Perilaku Wisatawan Mancanegara Pada Suatu Destinasi Pariwisata: Studi Kasus Bali Sebagai Destinasi Pariwisata Internasional." Vol. 5 No.1.5.1 
Sugiyono. 2012. Metode Penelitian Bisnis pendekatan Kuantitatif Kualitatif dan RED. Bandung: Alfabeta.

Sugiyono. 2015. Metode Penelitian Manajemen. Bandung: Alfabeta.

Supranto,J. 2006. Pengukuran Tingkat Kepuasan Pelanggan Untuk Menaikkan Pangsa Pasar. Jakarta: PT. Rineka Cipta.

Tjiptono, Fandy. 2002. Manajemen Jasa Edisi kedua. Yogyakarta : Andi.

Tjiptono, Fandy. 2014. Manajemen Jasa-Prinsip, Penerapan dan Penelitian. Yogyakarta: Andi.

Widarjono, Agus. 2010. Analisis Statistika Multivariate Terapan. Yogyakarta : UPP STIM YKPN.

Yoeti, Oka A. 2005. Perencanaan Strategis Pemasaran Daerah Tujuan Wisata. Jakarta: PT Pradnya Paramita.

\section{Profil Penulis}

I Made Weda Satia Negara, SST.Par adalah alumus Program Studi Magister Kajian Pariwisata Universitas Udayana. Ia menyelesaikan Program Diploma Empat (DIV) di Sekolah Tinggi Pariwisata Nusa Dua Bali pada tahun 2012 dan pada tahun 2015 melanjutkan Program Magister Kajian Pariwisata di Universitas Udayana dan tamat pada tahun 2018. Email : wedasatia.made@gmail.com.

Dr. I Nyoman Sudiarta, SE.,M.Par adalah Dosen Fakultas Pariwisata di Universitas Udayana. Meraih Gelar Doktor (S3) di Universitas Udayana pada tahun 2015. Meraih Gelar Magister Pariwisata pada tahun 2004. Meraih Gelar Sarjana (S1) di Sekolah Tinggi Ilmu Manajemen Indonesia Handayani pada tahun 2002. Email : sudiarta.nyoman@yahoo.co.id.

Dr. I Wayan Suardana, SST.Par.,M.Par adalah Dosen Fakultas Pariwisata di Universitas Udayana. Meraih Gelar Doktor (S3) di Universitas Udayana pada tahun 2015. Meraih Gelar Magister Pariwisata pada tahun 2004. Meraih Diploma IV (DIV) Fakultas Pariwisata di Universitas Udayana pada tahun 2001. Email: suar.dana@gmail.com. 